\title{
Detection of 140 clinically relevant antibiotic- resistance genes in the plasmid metagenome of wastewater treatment plant bacteria showing reduced susceptibility to selected antibiotics
}

Correspondence Andreas Schlüter Andreas.Schlueter@ Genetik.Uni-Bielefeld.de

Received 11 February 2009

Revised 3 April 2009

Accepted 8 April 2009
Rafael Szczepanowski, ${ }^{1}$ Burkhard Linke, ${ }^{2}$ Irene Krahn, ${ }^{1}$ Karl-Heinz Gartemann, ${ }^{3}$ Tim Gützkow, ${ }^{1}$ Wolfgang Eichler, ${ }^{4}$ Alfred Pühler ${ }^{1}$ and Andreas Schlüter ${ }^{1}$

${ }^{1}$ Institute for Genome Research and Systems Biology, Center for Biotechnology, Universität Bielefeld, Postfach 100131, D-33501 Bielefeld, Germany

${ }^{2}$ Bioinformatics Resource Facility, Center for Biotechnology, Universität Bielefeld, Postfach 100131, D-33501 Bielefeld, Germany

${ }^{3}$ Lehrstuhl für Gentechnologie und Mikrobiologie, Fakultät für Biologie, Universität Bielefeld, Universitätsstraße 25, D-33615 Bielefeld, Germany

${ }^{4}$ Landesamt für Natur, Umwelt und Verbraucherschutz NRW, FB76.2, Auf dem Draap 25, 40221 Düsseldorf, Germany

To detect plasmid-borne antibiotic-resistance genes in wastewater treatment plant (WWTP) bacteria, 192 resistance-gene-specific PCR primer pairs were designed and synthesized. Subsequent PCR analyses on total plasmid DNA preparations obtained from bacteria of activated sludge or the WWTP's final effluents led to the identification of, respectively, 140 and 123 different resistance-gene-specific amplicons. The genes detected included aminoglycoside, $\beta$ lactam, chloramphenicol, fluoroquinolone, macrolide, rifampicin, tetracycline, trimethoprim and sulfonamide resistance genes as well as multidrug efflux and small multidrug resistance genes. Some of these genes were only recently described from clinical isolates, demonstrating genetic exchange between clinical and WWTP bacteria. Sequencing of selected resistance-genespecific amplicons confirmed their identity or revealed that the amplicon nucleotide sequence is very similar to a gene closely related to the reference gene used for primer design. These results demonstrate that WWTP bacteria are a reservoir for various resistance genes. Moreover, detection of about $64 \%$ of the 192 reference resistance genes in bacteria obtained from the WWTP's final effluents indicates that these resistance determinants might be further disseminated in habitats downstream of the sewage plant.

\section{INTRODUCTION}

Development and dissemination of antibiotic-resistance genes is a serious problem in the treatment of infectious diseases (Goossens, 2005; Lim \& Webb, 2005). An important step in coping with this threat is to elucidate and to understand pathways for resistance gene spread. Many resistance genes are located on mobile genetic elements such as plasmids, transposons and integrons, which function as vectors for these determinants and promote their dissemination (Bennett, 1999; Davies, 1994; Davison, 1999; Hall \& Collis, 1995; Mazel \& Davies, 1999;

Abbreviation: WWTP, wastewater treatment plant.

A supplementary table of primers is available with the online version of this paper.
Rowe-Magnus \& Mazel, 1999; Seveno et al., 2002). Moreover, inappropriate use of antimicrobial drugs favours spread of resistance genes by selection for resistant micro-organisms (Bywater, 2004, 2005; Wassenaar, 2005).

Antibiotic-resistant bacteria of wastewater treatment plants (WWTPs) are the focus of the present study. WWTPs are connected to private households and hospitals where antibiotics are used and resistances in bacteria might arise. Once antibiotic-resistant bacteria reach WWTPs, they potentially can disseminate their resistance freight among members of the endogenous microbial community. Evidence for horizontal transfer of resistance elements in sewage habitats has been obtained for model systems (Geisenberger et al., 1999; Marcinek et al., 1998; Nüßlein et al., 1992). Because of the favourable growth conditions 
they provide for many micro-organisms, WWTPs have to be considered as hot-spots for horizontal transfer of genetic material, e.g. by means of conjugation (Mach \& Grimes, 1982; Mancini et al., 1987). In addition, contamination of sewage with antibiotics might cause a selective advantage for resistant bacteria (Göbel et al., 2005; Golet et al., 2002, 2003; Jarnheimer et al., 2004; Kümmerer, 2003; Kümmerer et al., 2000; Lee et al., 2007; Lindberg et al., 2005, 2006).

Previously, 12 different resistance plasmids, namely pB2/ pB3 (Heuer et al., 2004), pB4 (Tauch et al., 2003), pB8 (Schlüter et al., 2005), pB10 (Schlüter et al., 2003), pTB11 (Tennstedt et al., 2005), pRSB101 (Szczepanowski et al., 2004), pRSB105 (Schlüter et al., 2007a), pRSB107 (Szczepanowski et al., 2005), pRSB111 (Szczepanowski et al., 2007), pGNB1 (Schlüter et al., 2007b) and pGNB2 (Bönemann et al., 2006), were isolated from WWTP compartments and analysed at the genomic and functional level. These plasmids confer resistance to different antibiotics such as aminoglycosides, $\beta$-lactams, chloramphenicol, macrolides, quinolones, fluoroquinolones, tetracycline, trimethoprim and sulphonamides. In addition, some of the plasmids analysed carry heavy metal, quaternary ammonium compound or triphenylmethane dye resistance genes. Moreover, different class 1 integronspecific resistance gene cassettes were identified on plasmids from WWTP bacteria (Tennstedt et al., 2003). A total of 22 different resistance genes and 27 different integron-specific resistance gene cassettes were identified on plasmids harboured by bacteria of activated sludge and the WWTP's final effluents. Other studies investigated the occurrence of resistance genes in different aquatic systems including sewage habitats. Many of these studies focused either on selected antibiotic-resistance genes, e.g. vanC, ampC, mecA (Schwartz et al., 2003; Volkmann et al., 2004), or on genes conferring resistance to a specific class of antimicrobial compounds, e.g. $\beta$-lastams (Henriques et al., 2006a, b), chloramphenicol (Dang et al., 2008), or tetracyclines (Akinbowale et al., 2007; Chee-Sanford et al., 2001; Guillaume et al., 2000; Smith et al., 2004).

A more comprehensive study investigated the plasmid metagenome of WWTP bacteria with reduced susceptibility to certain antimicrobial drugs by applying the nextgeneration 454-pyrosequencing technology (Schlüter et al., 2008; Szczepanowski et al., 2008). This approach led to the identification of sequences that are very similar to 81 different antibiotic-resistance genes, three multidrug efflux genes and three quaternary ammonium compound resistance genes. However, detailed analysis of the plasmid metagenome dataset indicated that the corresponding sequencing approach was not carried out to saturation. Thus, it is very likely that low-abundance genes were not detected. Moreover, only one compartment of the wastewater treatment plant was investigated by the cited plasmid metagenome study.

Therefore, the present study was aimed at screening the same WWTP for the occurrence of a large set of known antibiotic-resistance genes by means of a PCR approach which should also allow for detection of low-abundance resistance genes. The identification of resistance genes involved design and testing of 192 resistance-gene-specific PCR primer pairs. The question of whether the set of resistance determinants could also be detected in the WWTP's final effluents was also addressed.

\section{METHODS}

Isolation of plasmids from resistant bacteria residing in activated sludge and the final effluents of the WWTP. The WWTP samples were taken in September 2006 from the municipal WWTP Bielefeld-Heepen, Germany. One litre of the final effluent sample was centrifuged $(5 \mathrm{~min}, 8000 \mathrm{~g}$ ) and the resulting pellet was resuspended in $5 \mathrm{ml}$ Luria Broth. Aliquots $(100 \mu \mathrm{l})$ of the resuspended final effluent sample and the activated sludge sample were plated in five replicates in serial dilutions onto Luria-Broth agar plates supplemented with one of the following antibiotics: $100 \mu \mathrm{g}$ ampicillin $\mathrm{ml}^{-1}, 1 \mu \mathrm{g}$ cefotaxime $\mathrm{ml}^{-1}, 15 \mu \mathrm{g}$ cefuroxime $\mathrm{ml}^{-1}, 25 \mu \mathrm{g}$ chloramphenicol ml $\mathrm{ml}^{-1}, 1 \mu \mathrm{g}$ ciprofloxacin $\mathrm{ml}^{-1}, 200 \mu \mathrm{g}$ erythromycin $\mathrm{ml}^{-1}, 15 \mu \mathrm{g}$ gentamicin $\mathrm{ml}^{-1}, 50 \mu \mathrm{g}$ kanamycin $\mathrm{ml}^{-1}, 1 \mu \mathrm{g}$ norfloxacin $\mathrm{ml}^{-1}, 30 \mu \mathrm{g}$ rifampicin $\mathrm{ml}^{-1}, 100 \mu \mathrm{g}$ spectinomycin $\mathrm{ml}^{-1}, 100 \mu \mathrm{g}$ streptomycin $\mathrm{ml}^{-1}, 5 \mu \mathrm{g}$ tetracycline $\mathrm{ml}^{-1}$. The agar medium was also supplemented with cycloheximide at a final concentration of $75 \mu \mathrm{g} \mathrm{ml} \mathrm{g}^{-1}$ to avoid growth of fungi. After incubation at $30{ }^{\circ} \mathrm{C}$ for $36 \mathrm{~h}$ the bacteria were collected separately for each antibiotic used for selection. Total plasmid DNAs from activated sludge or final effluent bacteria were prepared with the NucleoBond kit PC100 on AX 100 columns (Macherey-Nagel) according to the manufacturer's protocol. This method has been shown to be suitable for isolation of plasmids in a size range of 40 to $180 \mathrm{kbp}$ (Stiens et al., 2008; Szczepanowski et al., 2004), with the limitation that larger plasmids cannot be isolated with the same efficiency as smaller plasmids. It should also be mentioned here that the plasmid isolation procedure is biased by the lysis method implemented in the NucleoBond kit PC100 protocol since it cannot be assumed that all kinds of WWTP bacteria are equally well lysed by this method. After DNA isolation, a $\mathrm{CsCl}$ high-density gradient centrifugation (Sambrook et al., 1989) using a Vti 65.2 rotor was performed in order to minimize contamination with chromosomal DNA. Plasmid DNA concentrations were determined by using the NanoDrop 1000 instrument (NanoDrop Technologies). For further analyses, $20 \mu \mathrm{l}$ of each total plasmid DNA preparation (separately held for plasmid DNAs from activated sludge and final effluent bacteria) were mixed, resulting in two master total plasmid DNA samples.

Selection of target reference antibiotic-resistance genes and design of specific PCR primers. For the design of resistance-genespecific PCR primers, reference resistance gene nucleotide sequences were extracted from different databases: EBI SRS server (http:// srs.ebi.ac.uk/), NCBI (http://www.ncbi.nlm.nih.gov/), $\beta$-lactamase genes (http://www.lahey.org/Studies/) and macrolide and tetracycline resistance genes (http://faculty.washington.edu/marilynr/). In total, about 650 resistance and multidrug efflux permease gene sequences known to confer resistance to different antimicrobial compounds including aminoglycosides, $\beta$-lactams, chloramphenicol, macrolides, quinolones, fluoroquinolones, rifampicin, tetracyclines, trimethoprim, sulphonamides and quaternary ammonium compounds were selected from these databases. A new database, named ARG-DB (Antibiotic Resistance Gene Database), was set up for the extracted genes and all entries of ARG-DB were compared to each other by applying the BLAST algorithm. Genes with more than $85 \%$ sequence 
identity were clustered. Based on CLUSTAL w (Larkin et al., 2007) alignments, a consensus sequence was calculated for each cluster and the gene showing the highest degree of identity to the consensus sequence was defined as representative for the respective cluster. This approach led to the selection of 192 reference resistance genes (see Table 1 and Supplementary Table S1, available with the online version of this paper) each representing a distinct alignment cluster. Specific PCR primers were designed for all reference genes by means of the Primer3 program (Rozen \& Skaletsky, 2000) and synthesized. The resulting PCR primer sequences are shown in Table S1. Plasmid incompatibility genes specific for the Inc groups P, Q, W, N (Götz et al., 1996), A/C (Llanes et al., 1996) and F (Eichenlaub et al., 1977) as well as the genes gfp (Prasher et al., 1992) and luc (accession no. D25416) were chosen as control sequences for primer design.

PCR and amplicon detection. The reaction mix of the PCR was composed of approximately $100 \mathrm{ng}$ total plasmid DNA as template, $2.5 \mu$ reaction buffer $(10 \times), 2 \mathrm{mM} \mathrm{MgCl}_{2}, 0.2 \mathrm{mM}$ of each dNTP,

Table 1. Selected reference antibiotic-resistance genes, and corresponding enzymes

The genes are grouped according to the antimicrobial drug class to which they confer resistance.

\begin{tabular}{|c|c|c|}
\hline Antimicrobial compound class & Encoded enzymes & Gene names \\
\hline \multirow[t]{3}{*}{ Aminoglycosides } & Aminoglycoside acetyltransferases & $\begin{array}{l}a a c A, a a c A 1, a a c A 4, a a c A 7, a a c A 29 b, a a c C 1, a a c C 2, a a c C 3 \\
a a c C 4, a a c(3)-I d, a a c\left(6^{\prime}\right)-\operatorname{Im}\end{array}$ \\
\hline & Aminoglycoside adenylyltransferases & aadA4, aadA7, aadA9, aadA10, aadA12, aadD \\
\hline & Aminoglycoside phosphotransferases & $a p h, a p h A, a p h A-3, a p h A-6, a p h A-7, a p h 2, a p h\left(2^{\prime}\right)-I b, \operatorname{str} A, \operatorname{str} B$ \\
\hline \multirow[t]{4}{*}{$\beta$-Lactams } & Class A $\beta$-lactamases & $\begin{array}{l}c t x-m 4, c t x-m 26, c t x-m 27, c t x-m 32, \text { ges-3, } k p c-3, \text { per- } 1, \text { per- } 2 \\
s h v-34, b l a_{\mathrm{TEM}-1}, b l a_{\mathrm{TLA}-1}, b l a_{\mathrm{TLA}-2}, v e b-1\end{array}$ \\
\hline & Class B $\beta$-lactamases & $i m p-2, i m p-5, i m p-9, i m p-13, i m p-16, i m p-16, v i m-4, v i m-7$ \\
\hline & Class C $\beta$-lactamases & $a m p C, c m y-9, c m y-13$ \\
\hline & Class D $\beta$-lactamases & 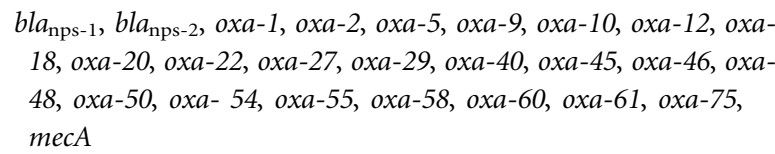 \\
\hline \multirow[t]{3}{*}{ Chloramphenicol/florfenicol } & Chloramphenicol acetyltransferases & $\begin{array}{l}\text { cat, cat, cat, cat, cat } 2, \text { catIII, cat } A, \text { catB2, catB4, catB6, catB7, } \\
\text { catB8, catB9, catP, cat-TC }\end{array}$ \\
\hline & Chloramphenicol/florfenicol transporters & cmlA1, cmxA, fexA, floR \\
\hline & Hydrophobic polypeptide & $\mathrm{cmlB}$ \\
\hline Fluoroquinolones & Pentapeptide family proteins & $q n r A 3, q n r B 1, q n r B 4, q n r$ \\
\hline \multirow[t]{6}{*}{ Macrolides } & rRNA adenine $N^{6}$-methyltransferases & $\operatorname{erm} A, \operatorname{erm} B, \operatorname{erm} D, \operatorname{erm} F, \operatorname{erm}(A), \operatorname{erm}(T R)$ \\
\hline & Esterase & ereA2, ereB \\
\hline & MFS efflux proteins & $m e f A$, mefE, mefE, mel, msr(A) \\
\hline & Macrolide 2'-phosphotransferases & $m p h(B), m p h(A), m p h, m p h B, m p h(B M)$ \\
\hline & Hydrolase & $\operatorname{vgh}(A)$ \\
\hline & Streptogramin B lactonase & $v g b B$ \\
\hline Rifampicin & ADP-ribosylating transferase & $\operatorname{arr} 2$ \\
\hline \multirow[t]{7}{*}{ Tetracyclines } & Tetracycline transporters & $\begin{array}{l}\operatorname{tet}(\mathrm{A}), \operatorname{tet}(\mathrm{A}), \operatorname{tet} A(\mathrm{C}), \operatorname{tet} \mathrm{A}(\mathrm{\textrm {E }}), \operatorname{tet} \mathrm{A}(\mathrm{J}), \operatorname{tet} B S R, \operatorname{tet}(\mathrm{D}), \operatorname{tet}(\mathrm{G}), \\
\operatorname{tet}(\mathrm{H}), \operatorname{tet}(\mathrm{L}), \operatorname{tet} \mathrm{A}(\mathrm{Y}), \operatorname{tet}(\mathrm{Z}), \operatorname{effJ}, \operatorname{tet}(\mathrm{V}), \operatorname{tet}(\mathrm{K}), \operatorname{tet}(30), \\
\operatorname{tet}(33), \operatorname{tet}(38), \operatorname{tet} \mathrm{A}(39)\end{array}$ \\
\hline & Tetracycline inactivation proteins & $\operatorname{tet}(37), \operatorname{tet}(\mathrm{X})$ \\
\hline & GTP-binding elongation factor proteins & $\begin{array}{l}\operatorname{tet} B(\mathrm{P}), \operatorname{tet}(\mathrm{M}), \operatorname{tet}(\mathrm{M}), \operatorname{tet}(\mathrm{M}), \operatorname{tet}(\mathrm{M}), \operatorname{tet}(\mathrm{O}), \operatorname{tet}(\mathrm{S}), \operatorname{tet}(\mathrm{W}), \\
\operatorname{tet}(32)\end{array}$ \\
\hline & $\begin{array}{l}\text { Ribosomal protection tetracycline } \\
\text { resistance proteins }\end{array}$ & $\operatorname{tet}(36), \operatorname{tet} \mathrm{Q}, \operatorname{tet}(\mathrm{T})$ \\
\hline & Tetracycline repressor protein & $\operatorname{tet} \mathrm{R}(31)$ \\
\hline & Tetracycline resistance & $\operatorname{tet}(\mathrm{U})$ \\
\hline & Phosphoribosyltransferase & $\operatorname{tet}(34)$ \\
\hline Trimethoprim & Dihydrofolate reductases & $\begin{array}{l}d f r I I, d f r V, d f r V I, d f r X I I, d f r 13, d f r 16, d f r 17, d f r A 19, d f r B 2, d f r D, \\
d h f r, d h f R, d h f r I, d h f r V I I I, d h f r I X, d h f r X V\end{array}$ \\
\hline Sulfonamides & Dihydropteroate synthetases & sulI, sulII, sulIII \\
\hline $\begin{array}{l}\text { Quaternary ammonium } \\
\text { compounds }\end{array}$ & Small multidrug efflux proteins & $q a c B, q a c D, q a c E \Delta 1, q a c F, q a c F, q a c G, q a c G 2, q a c H$ \\
\hline $\begin{array}{l}\text { Various antibiotics } \\
\text { transported by multidrug } \\
\text { efflux genes }\end{array}$ & Multidrug efflux pumps & $\operatorname{acr} B, \operatorname{acr} D, \operatorname{mex} B, \operatorname{mex} D, \operatorname{mex} D, \operatorname{mexF}$, mexI, mexY, orf11 \\
\hline Total & & 192 \\
\hline
\end{tabular}


$0.5 \mu \mathrm{M}$ of each primer, $1 \mathrm{U}$ Taq DNA polymerase (BioLine), and filled up to $25 \mu \mathrm{l}$ with sterile double-distilled water. The initial step of the reaction was denaturation of DNA at $94{ }^{\circ} \mathrm{C}$ for $4 \mathrm{~min}$. This step was followed by 35 cycles composed of 1 min denaturation at $94{ }^{\circ} \mathrm{C}$, $1 \mathrm{~min}$ annealing at $58{ }^{\circ} \mathrm{C}$ and $45 \mathrm{~s}$ polymerization at $72{ }^{\circ} \mathrm{C}$. The final polymerization step was performed for $10 \mathrm{~min}$ at $72{ }^{\circ} \mathrm{C}$. The amplicons were analysed by gel electrophoresis (in $1 \%$ agarose in Tris/ $\mathrm{HCl} /$ acetate buffer), stained with ethidium bromide and visualized under UV light.

Sequencing and analysis of selected resistance-gene-specific amplicons. After filter purification by means of MAHVN 4550 (Millipore) and G-50 Fine Sephadex (Sigma-Aldrich) the amplicons were sequenced on an ABI $3730 \mathrm{XL}$ sequencer (Applera, Applied Biosystems) using Big Dye 3.1 chemistry. Assembly of the forward and reverse sequence of each amplicon, and sequence quality control, was carried out by means of the CONSED/AUTOFINISH software tool (Gordon et al., 1998, 2001). Assembled resistance-gene-specific amplicon sequences were compared to the NCBI nucleotide sequence database by means of BLAST (Altschul et al., 1990).

\section{RESULTS AND DISCUSSION}

\section{Isolation of antibiotic-resistance plasmids from resistant bacteria obtained from activated sludge and the WWTP's final effluents}

To get an overview of the occurrence of resistance determinants in a WWTP habitat, total plasmid DNA preparations isolated from antibiotic-resistant WWTP bacteria were probed for different known resistance genes by means of a PCR approach. Antibiotic-resistant bacteria originating from activated sludge or from the final effluent compartment of the municipal WWTP Bielefeld-Heepen were selected on media supplemented with one of 12 clinically relevant antibiotics (see Methods). Total plasmid DNA was prepared from bacteria able to grow on these selective media and used as template in PCR analyses for the detection of selected resistance determinants. The concentration of the pooled template DNAs was about $80 \mathrm{ng} \mathrm{\mu l}^{-1}$ for each habitat (activated sludge and final effluents). Target reference resistance genes were extracted from different nucleotide sequence databases, and gene-specific PCR primers were designed (see Supplementary Table S1).

\section{Detection of plasmid-encoded resistance genes in resistant bacteria isolated from activated sludge and the WWTP's final effluents}

To detect resistance genes and plasmid incompatibility determinants present in bacteria residing in activated sludge and the final effluent compartment of the WWTP, PCR analyses using 200 specific primer pairs were carried out. Total plasmid DNA preparations from antibioticresistant WWTP bacteria were used as template DNAs in these PCRs. In total, 145 amplicons (140 specific for resistance genes and five for plasmid incompatibility determinants) were obtained in these PCRs on total plasmid DNA from antibiotic-resistant activated-sludge bacteria (Table 2). The total plasmid DNA preparation originating from bacteria of the final-effluent compartment yielded 129 amplicons (123 specific for resistance genes and six for plasmid-specific genes) (Table 2). PCR results were positive for resistance genes known to confer resistance to different aminoglycoside, $\beta$-lactam, chloramphenicol, fluoroquinolone, macrolide, rifampicin, tetracycline, trimethoprim and sulfonamide antibiotics as well as to quaternary ammonium compounds (Table 2).

Results of this study were compared to the plasmid metagenome data that were recently obtained for activated sludge bacteria showing reduced susceptibility to selected antimicrobial drugs from the same WWTP. High-throughput 454-pyrosequencing of plasmids from these bacteria revealed that numerous sequences are very similar or even identical to 81 known antibiotic-resistance genes conferring resistance to the major classes of antimicrobial drugs (Schlüter et al., 2008; Szczepanowski et al., 2008). The PCR-based approach led to the detection of 59 additional resistance genes in activated-sludge bacteria that were not apparent in the plasmid metagenome dataset. For instance, 15 additional tetracycline resistance genes appeared in the PCR analysis. In contrast, only sequences for seven different tetracycline-resistance genes, namely tet $A(\mathrm{~A})$, $\operatorname{tet} A(\mathrm{~B}), \operatorname{tet} A(\mathrm{C}), \operatorname{tet} A(\mathrm{D}), \operatorname{tet} A(\mathrm{E}), \operatorname{tet} A(\mathrm{X})$ and $\operatorname{tet}(39)$, were identified in the metagenome dataset (Schlüter et al., 2008; Szczepanowski et al., 2008). Moreover, the PCRbased approach led to the detection of 123 different plasmid-encoded resistance-gene-specific amplicons in bacteria isolated from the final effluent of the WWTP analysed here. This compartment was not covered by the cited plasmid metagenome study.

The present study also showed that the resistance gene spectra detected in plasmid DNA preparations originating from activated-sludge and from final-effluent bacteria are quite similar. Only the numbers of detected aminoglycoside, $\beta$-lactam, macrolide and tetracycline resistance genes differ slightly for the WWTP compartments tested. Interestingly, the same fluoroquinolone, trimethoprim and sulfonamide resistance genes as well as the same genes for multidrug efflux systems could be detected in both plasmid samples (see Table 2). This high congruence of amplicons for the latter resistance genes may be explained by the fact that antibiotics, especially fluoroquinolones, trimethoprim and sulfonamides, are only poorly removed during wastewater treatment processes (Göbel et al., 2005; Golet et al., 2002, 2003; Lindberg et al., 2005, 2006; Nakata et al., 2005) and therefore might exert selective pressure on bacteria within the sewer system or the sewage plant, leading to enrichment of resistant bacteria and their release into the environment with the final effluents.

\section{Detection of resistance genes recently described from clinical isolates in the WWTP compartments analysed}

Detection of numerous and various resistance genes in bacteria from activated sludge (140 genes) and the final 
Table 2. Resistance genes detected by PCR in total plasmid DNA preparations isolated from bacteria of activated sludge or the WWTP's final effluent

\begin{tabular}{|c|c|c|c|c|c|c|}
\hline Gene name $e^{\star}$ & Gene product & $\begin{array}{l}\text { Amplicon size } \\
\text { (bp) }\end{array}$ & $\begin{array}{l}\text { Resistance to/ } \\
\text { function } \dagger\end{array}$ & $\begin{array}{l}\text { Detected in } \\
\text { activated sludge }\end{array}$ & $\begin{array}{l}\text { Detected in the } \\
\text { final effluents }\end{array}$ & Accession no. \\
\hline $\operatorname{aac} A, \operatorname{aadB}$ & Aminoglycoside $6^{\prime}-N$-acetyltransferase & 197 & $\mathrm{Km}$, Tob, Ak & + & + & M86913 \\
\hline aacA1 & Aminoglycoside $6^{\prime}$ - $N$-acetyltransferase & 200 & $\mathrm{Gm}, \mathrm{Km}, \mathrm{Tob}, \mathrm{Neo}$ & + & - & AB113580 \\
\hline aacA4 & Aminoglycoside 6 '-acetyltransferase & 196 & $\mathrm{Ak}$ & + & + & AJ744860 \\
\hline aacA7 & Aminoglycoside acetyltransferase- $6^{\prime}$ type I & 175 & $\mathrm{Gm}$, Tob, Km & + & - & AF263520 \\
\hline$a a c A 29 b$ & Aminoglycoside $6^{\prime}-N$-acetyltransferase & 170 & $\mathrm{Ak}, \mathrm{Km}$ & + & + & AY139599 \\
\hline $\operatorname{aacC1}$ & Aminoglycoside $3 N$-acetyltransferase & 130 & $\mathrm{Gm}$ & + & + & AY139604 \\
\hline $\operatorname{aacC2}$ & Aminoglycoside (3)- $N$-acetyltransferase & 148 & $\mathrm{Gm}$ & + & + & S68058 \\
\hline aacC4 & Aminoglycoside (3)-acetyltransferase IV & 147 & $\mathrm{Gm}$ & + & + & X01385 \\
\hline $\operatorname{aac}(3)-I d \ddagger$ & $3^{\prime}-N$-Aminoglycoside acetyltransferase & 178 & $\mathrm{Gm}$ & + & + & AY458224 \\
\hline $\operatorname{aac}\left(6^{\prime}\right)-\operatorname{Im}$ & $6^{\prime}$-Aminoglycoside $N$-acetyltransferase & 194 & Tob, Ak, Km & + & + & AF337947 \\
\hline aadA4, aadA5 & Streptomycin $3^{\prime}$-adenylyltransferase & 198 & $\mathrm{Sm}, \mathrm{Sp}$ & + & + & AY138986 \\
\hline aadA7 & Aminoglycoside $\left(3^{\prime}\right)(9)$-adenylyltransferase & 187 & $\mathrm{Sm}, \mathrm{Sp}$ & + & + & AY463797 \\
\hline $\operatorname{aad} 99$ & Streptomycin $3^{\prime}$-adenylyltransferase & 184 & $\mathrm{Sm}, \mathrm{Sp}$ & + & - & AJ420072 \\
\hline aadA10, aadA6/aadA10 $\ddagger$ & Aminoglycoside $\left(3^{\prime}\right)(9)$-adenylyltransferase & 198 & $\mathrm{Sm}, \mathrm{Sp}$ & + & + & U37105 \\
\hline $\begin{array}{l}\text { aadA12, aadA1, aadA2, } \\
\text { aadA8, aadA11, aadA13, } \\
\text { aadA23 }\end{array}$ & Putative streptomycin 3 -adenylyltransferase & 186 & Putative Sm, Sp & + & + & AY665771 \\
\hline$a a d D$ & Kanamycin-nucleotidyltransferase & 153 & $\mathrm{Km}$ & + & + & AB037420 \\
\hline$a p h$ & Aminoglycoside 3'-phosphotransferase & 173 & $\mathrm{Km}, \mathrm{Neo}$ & + & + & AJ851089 \\
\hline aphA & $3^{\prime}$-Aminoglycoside phosphotransferase & 198 & $\mathrm{Km}$ & + & + & AJ744860 \\
\hline aphA-3 & $3^{\prime} 5^{\prime}$-Aminoglycoside phosphotransferase of type III & 139 & $\mathrm{Km}$ & + & + & V01547 \\
\hline aphA-6 & $3^{\prime}$-Aminoglycoside phosphotransferase & 192 & $\mathrm{Km}, \mathrm{Ak}$ & + & + & X07753 \\
\hline aph2 & Aminoglycoside-3'-O-phosphotransferase & 198 & $\mathrm{Km}, \mathrm{Neo}$ & + & + & U00004 \\
\hline $\operatorname{aph}\left(2^{\prime}\right)-I b$ & Aminoglycoside phosphotransferase & 175 & $\mathrm{Km}$ & + & - & AF337947 \\
\hline strA & Aminoglycoside $3^{\prime}$-phosphotransferase & 196 & $\mathrm{Sm}$ & + & + & NC_004840 \\
\hline $\operatorname{str} B$ & Aminoglycoside 6-phosphotransferase & 150 & Sm & + & + & NC_004840 \\
\hline$c t x-m-4$ & Class A $\beta$-lactamase & 155 & Amp, Ctx, Cxm, Atm & + & + & Y14156 \\
\hline$c t x-m-27 \ddagger$ & Class A $\beta$-lactamase & 158 & $\begin{array}{l}\text { Caz, Ctx, Amo, Tic, Prl, Kf, } \\
\text { Cxm, Cpo, Atm }\end{array}$ & + & + & AY156923 \\
\hline$c t x-m-32 \ddagger$ & Class A $\beta$-lactamase & 156 & $\begin{array}{l}\text { Amo, Ctx, Caz, Fep, Prl, Kf, } \\
\text { Fox, Cxm }\end{array}$ & + & + & AJ557142 \\
\hline ges-3 & Class A extended-spectrum $\beta$-lactamase & 181 & $\begin{array}{l}\text { Titeracillin, Prl, Caz, Ctx, Atm, } \\
\text { Ipm }\end{array}$ & + & + & AY494717 \\
\hline per-2 & Class A extended-spectrum $\beta$-lactamase & 198 & $\begin{array}{l}\text { Oxyiminocephalosporins, Atm, } \\
\mathrm{Cft}\end{array}$ & + & - & X93314 \\
\hline $\operatorname{shv-34}$ & Class A $\beta$-lactamase & 200 & $\mathrm{Caz}, \mathrm{Ctx}$ & + & + & AY036620 \\
\hline$b l a_{\mathrm{TEM}-1}$ & Class A $\beta$-lactamase & 167 & Amp, Pen-G & + & + & AJ851089 \\
\hline$b l a_{\mathrm{TLA}-2}$ & Class A extended spectrum $\beta$-lactamase & 186 & $\begin{array}{l}\text { Amo, Tic, Caz, Kf, Cxm, Fox, } \\
\text { Ctx, Fep, Atm }\end{array}$ & + & + & NC_006385 \\
\hline$v e b-1$ & Class A extended-spectrum $\beta$-lactamase & 190 & Cephalosporins, Atm & + & - & AF010416 \\
\hline vim-4 & Metallo- $\beta$-lactamase & 171 & $\beta$-Lactams & - & + & AY509609 \\
\hline
\end{tabular}

Metallo- $\beta$-lactamase

Cephalosporins, Atm

$+$

AF010416 
Table 2. cont.

\begin{tabular}{|c|c|c|c|c|c|c|}
\hline Gene name ${ }^{\star}$ & Gene product & $\begin{array}{l}\text { Amplicon size } \\
\text { (bp) }\end{array}$ & $\begin{array}{l}\text { Resistance to/ } \\
\text { function } \dagger\end{array}$ & $\begin{array}{c}\text { Detected in } \\
\text { activated sludge }\end{array}$ & $\begin{array}{l}\text { Detected in the } \\
\text { final effluents }\end{array}$ & Accession no. \\
\hline$i m p-2, i m p-5$ & Class B metallo $\beta$-lactamase & 200 & Amp, Ctx, Fep & + & + & AJ243491 \\
\hline$i m p-9 \ddagger$, imp-11 & Class B metallo $\beta$-lactamase & 178 & $\beta$-Lactams & + & + & AY033653 \\
\hline$i m p-13, i m p-2$ & Class B metallo $\beta$-lactamase & 198 & Cxm, Caz, Ctx, Cro, Fep, Amp & + & + & AJ550807 \\
\hline $\operatorname{ampC}$ & Class C $\beta$-lactamase, cephalosporinase & 189 & Pen, cephalosporins & + & + & J01611 \\
\hline cmy-9, cmy-10 & Class C $\beta$-lactamase & 169 & $\beta$-Lactams & + & + & AB061794 \\
\hline$c m y-13 \ddagger, c m y-5$ & Class C $\beta$-lactamase & 150 & $\beta$-Lactams & + & + & AY339625 \\
\hline$b l a_{\mathrm{NPS}-1}$ & Class D $\beta$-lactamase & 188 & $\begin{array}{l}\text { Amo, azlocillin, Cec, cefazolin, } \\
\text { Cfp, Prl }\end{array}$ & + & - & NC_003430 \\
\hline$b l a_{\mathrm{NPS}-2}$ & Class D $\beta$-lactamase & 192 & Amp & + & + & NC_006388 \\
\hline oxa-1 & Class D $\beta$-lactamase & 199 & $\beta$-Lactams & + & + & AY139600 \\
\hline oxa -2, oxa -21, oxa -53 & Class D $\beta$-lactamase & 177 & $\beta$-Lactams & + & + & NC_007502 \\
\hline oxa-5 & Class D $\beta$-lactamase & 175 & $\beta$-Lactams & + & + & X58272 \\
\hline oxa-9 & Class D $\beta$-lactamase & 162 & $\beta$-Lactams & + & - & M55547 \\
\hline oxa -10, oxa-56 & Class D $\beta$-lactamase & 191 & $\beta$-Lactams & + & + & AY115475 \\
\hline oxa-12 & Class D $\beta$-lactamase & 188 & $\beta$-Lactams & + & + & U10251 \\
\hline oxa -20 & Class D $\beta$-lactamase & 163 & Amo, Tic & - & + & AF024602 \\
\hline oxa-22 & Class D $\beta$-lactamase & 200 & Benzylpenicillin, $\mathrm{Ob}$ & + & + & AF064820 \\
\hline oxa-27 & Class D $\beta$-lactamase & 180 & $\beta$-Lactams & + & - & AF201828 \\
\hline oxa-40 & Class D $\beta$-lactamase & 168 & $\begin{array}{l}\text { Amo, Tic, Caz, Fep, Cpo, Prl, } \\
\text { Kf, Cxm, Ipm }\end{array}$ & + & + & AF509241 \\
\hline oxa-46, oxa & Class D $\beta$-lactamase & 150 & Amp, Car, Mez, Kf & + & + & AF317511 \\
\hline oxa-48 & Class D $\beta$-lactamase & 145 & $\begin{array}{l}\text { Amo, Tic, Fep, Ipm, Cpo, Prl, } \\
\text { Ctx }\end{array}$ & + & + & AY236073 \\
\hline oxa-50 & Class D $\beta$-lactamase & 198 & Amp, Tic, Ctx, Prl, Kf, Cxm & + & + & AY306130 \\
\hline$o x a-58$ & Class D $\beta$-lactamase & 152 & Amo, Tic, Cpo, Prl, Ipm, Kf & + & + & AY665723 \\
\hline oxa-75 & Class D $\beta$-lactamase & 181 & Amp, Prl & + & + & AY859529 \\
\hline cmlA1, cmlA5 & Chloramphenicol efflux protein & 137 & $\mathrm{Cm}$ & + & + & NC_006388 \\
\hline $\mathrm{cmlB}$ & Hydrophobic polypeptide & 147 & $\mathrm{Cm}$ & + & + & AF034958 \\
\hline$c m x A$ & Chloramphenicol export protein & 186 & $\mathrm{Cm}$ & + & + & AF024666 \\
\hline fexA & Florfenicol/chloramphenicol exporter & 198 & $\mathrm{Cm}, \mathrm{Ffc}$ & + & - & AJ549214 \\
\hline floR, cmlA & Efflux protein & 188 & $\mathrm{Cm}, \mathrm{Ffc}$ & + & + & AF118107 \\
\hline cat & Chloramphenicol acetyltransferase & 173 & $\mathrm{Cm}$ & + & + & M11587 \\
\hline cat & Chloramphenicol acetyltransferase & 162 & $\mathrm{Cm}$ & + & + & M35190 \\
\hline cat & Chloramphenicol acetyltransferase & 195 & $\mathrm{Cm}$ & + & + & S48276 \\
\hline cat & Chloramphenicol acetyltransferase & 163 & $\mathrm{Cm}$ & + & + & M58515 \\
\hline cat2, catII, cmlA & Chloramphenicol acetyltransferase & 192 & $\mathrm{Cm}$ & + & + & AY509004 \\
\hline catIII & Chloramphenicol acetyltransferase & 150 & $\mathrm{Cm}$ & + & + & X07848 \\
\hline catA & Chloramphenicol acetyltransferase & 186 & $\mathrm{Cm}$ & + & + & AJ851089 \\
\hline catB2 & Chloramphenicol acetyltransferase & 156 & $\mathrm{Cm}$ & + & + & AY139601 \\
\hline catB4 & Chloramphenicol acetyltransferase & 188 & $\mathrm{Cm}$ & + & + & AF322577 \\
\hline
\end{tabular}


Table 2. cont.

\begin{tabular}{|c|c|c|c|c|c|c|}
\hline Gene name ${ }^{\star}$ & Gene product & $\begin{array}{l}\text { Amplicon size } \\
\text { (bp) }\end{array}$ & $\begin{array}{l}\text { Resistance to/ } \\
\text { function } \dagger\end{array}$ & $\begin{array}{l}\text { Detected in } \\
\text { activated sludge }\end{array}$ & $\begin{array}{l}\text { Detected in the } \\
\text { final effluents }\end{array}$ & Accession no. \\
\hline catB6 & Chloramphenicol acetyltransferase & 144 & $\mathrm{Cm}$ & - & + & AJ223604 \\
\hline catB7 & Chloramphenicol acetyltransferase & 152 & $\mathrm{Cm}$ & + & + & AF036933 \\
\hline catB8 & Chloramphenicol acetyltransferase & 175 & $\mathrm{Cm}$ & + & + & AF227506 \\
\hline cat-TC, cat & Chloramphenicol acetyltransferase & 194 & $\mathrm{Cm}$ & + & + & U75299 \\
\hline$q n r A 3 \ddagger, q n r$ & $\begin{array}{l}\text { Pentapeptide family, DNA-gyrase and topoisomerase } \\
\text { IV protection }\end{array}$ & 168 & $\mathrm{Nal}$ & + & + & DQ058661 \\
\hline$q n r B 1 \neq, q n r B 2, q n r B 5$ & $\begin{array}{l}\text { Pentapeptide family, DNA-gyrase and topoisomerase } \\
\text { IV protection }\end{array}$ & 191 & Cip & + & + & DQ351241 \\
\hline qnrB4 & Pentapeptide family & 158 & Quinolones & + & + & DQ303921 \\
\hline$q n r, q n r S 2 \ddagger$ & Quinolone resistance determinant & 175 & Cip, Nor, Nal & + & + & $\mathrm{AB} 187515$ \\
\hline ereA2, ereA & Erythromycin esterase type I & 177 & $\mathrm{Em}$ & + & + & AF512546 \\
\hline ereB & Erythromycin esterase type II & 158 & $\mathrm{Em}$ & + & - & X03988 \\
\hline$m p h(B)$ & Macrolide phosphotransferase & 199 & Azi, Cla, Em, Rox, Tyl & + & + & AM260957 \\
\hline$m p h(A)$ & Macrolide $2^{\prime}$-phosphotransferase I & 153 & Azi, Cla, Em, Rox & + & + & NC_006385 \\
\hline$m p h$ & Macrolide 2'-phosphostransferase & 200 & Em & + & + & DQ839391 \\
\hline$m p h(B)$ & Macrolide 2'-phosphotransferase II & 200 & Macrolides & + & + & D85892 \\
\hline$m p h B M$ & Macrolide 2'-phosphotransferase II & 200 & Macrolides & + & - & AF167161 \\
\hline $\operatorname{ermA}$ & rRNA adenine $N^{6}$-methyltransferase & 185 & Em & + & - & X51472 \\
\hline ermB & rRNA adenine $N^{6}$-methyltransferase & 193 & Em & + & + & M11180 \\
\hline ermF & rRNA adenine $N^{6}$-methyltransferase & 323 & MLS & + & + & M14730 \\
\hline$m e f(\mathrm{~A})$ & Macrolide-efflux protein, MFS permease & 179 & Em & + & - & AJ715499 \\
\hline mefE, mefI & Macrolide-efflux protein, MFS permease & 199 & Em & + & - & AF274302 \\
\hline mel & $\begin{array}{l}\text { Macrolide-efflux protein, macrolide-specific ABC- } \\
\text { type efflux carrier }\end{array}$ & 198 & Azi, Cla, Em & + & + & DQ839391 \\
\hline$m s r A$ & Erythromycin resistance ATP-binding protein MsrA & 158 & Em & + & - & X52085 \\
\hline $\operatorname{arr} 2$ & Putative rifampicin ADP-ribosyltransferase & 140 & Rif & + & + & AF205943 \\
\hline sulI & Dihydropteroate synthetase & 185 & Sul & + & + & NC_006388 \\
\hline sulII & Dihydropteroate synthetase & 147 & Sul & + & + & AJ851089 \\
\hline sul3 & Dihydropteroate synthetase & 199 & Sul & + & + & AY316203 \\
\hline$d f r I I$ & Dihydrofolate reductase & 156 & $\mathrm{Tp}$ & + & + & AY139601 \\
\hline$d f r V$ & Dihydrofolate reductase & 180 & $\mathrm{Tp}$ & + & + & AY139589 \\
\hline$d f r 13(d f r X I I I)$ & Dihydrofolate reductase & 174 & $\mathrm{Tp}$ & + & + & Z50802 \\
\hline$d f r 16$ & Dihydrofolate reductase & 173 & $\mathrm{Tp}$ & + & + & AY259085 \\
\hline$d f r 17, d f r V I I$ & Dihydrofolate reductase & 152 & $\mathrm{Tp}$ & + & + & AY139588 \\
\hline dfrA19 & Dihydrofolate reductase & 165 & $\mathrm{Tp}$ & + & + & AM234698 \\
\hline$d f r B 2$ & Dihydrofolate reductase & 198 & $\mathrm{Tp}$ & + & + & AY139592 \\
\hline$d f r D$ & Dihydrofolate reductase & 194 & $\mathrm{Tp}$ & + & + & Z50141 \\
\hline$d h f r 1$ & Dihydrofolate reductase & 169 & $\mathrm{Tp}$ & + & + & AJ698325 \\
\hline dhfrVIII & Dihydrofolate reductase & 169 & $\mathrm{Tp}$ & + & + & U10186 \\
\hline$d h f r X V$ & Dihydrofolate reductase & 197 & $\mathrm{Tp}$ & + & + & Z83311 \\
\hline
\end{tabular}




\begin{tabular}{|c|c|c|c|c|c|c|}
\hline Gene name ${ }^{\star}$ & Gene product & $\begin{array}{l}\text { Amplicon size } \\
\text { (bp) }\end{array}$ & $\begin{array}{l}\text { Resistance to/ } \\
\text { function } \dagger\end{array}$ & $\begin{array}{l}\text { Detected in } \\
\text { activated sludge }\end{array}$ & $\begin{array}{l}\text { Detected in the } \\
\text { final effluents }\end{array}$ & Accession no. \\
\hline tetA & MFS tetracycline efflux & 200 & Tc & + & + & NC_004840 \\
\hline tetA & MFS tetracycline efflux & 198 & Tc & + & + & NC_006388 \\
\hline tetA & MFS tetracycline efflux & 187 & Tc & + & + & AJ851089 \\
\hline tet $A$ & MFS tetracycline efflux & 176 & $\mathrm{Tc}$ & + & + & L06940 \\
\hline tetD & MFS tetracycline efflux & 155 & $\mathrm{Tc}$ & + & + & L06798 \\
\hline $\operatorname{tet} G$ & MFS tetracycline efflux & 140 & $\mathrm{Tc}$ & + & + & AF133139 \\
\hline tet $H$ & MFS tetracycline efflux & 164 & Tc & + & + & AJ245947 \\
\hline tet $L$ & MFS tetracycline efflux & 176 & Tc & + & - & U17153 \\
\hline $\operatorname{tet}(\mathrm{U})$ & Replication & 198 & Low level Tc & + & + & U01917 \\
\hline tet $Y$ & MFS tetracycline efflux & 146 & $\mathrm{Tc}$ & + & + & AF070999 \\
\hline $\operatorname{tet} R(31)$ & Tetracycline repressor protein & 168 & $\begin{array}{l}\text { Regulates expression of } \\
\operatorname{Tet} \mathrm{A}(31)\end{array}$ & + & + & AJ250203 \\
\hline effJ $($ tet(35)) & Putative tetracycline efflux pump & 190 & Tc & - & + & AF35362 \\
\hline $\operatorname{tet}(39)$ & MFS tetracycline efflux & 154 & Tc & + & + & AY743590 \\
\hline $\operatorname{tet} B(\mathrm{P})$ & $\begin{array}{l}\text { GTP-binding elongation factor protein, TetM/TetO } \\
\text { family }\end{array}$ & 143 & $\mathrm{Tc}$ & + & - & L20800 \\
\hline $\operatorname{tet}(\mathrm{M})$ & $\begin{array}{l}\text { GTP-binding elongation factor protein, TetM/TetO } \\
\text { family }\end{array}$ & 197 & Tc & + & + & M21136 \\
\hline $\operatorname{tet}(\mathrm{M})$ & $\begin{array}{l}\text { GTP-binding elongation factor protein, TetM/TetO } \\
\text { family }\end{array}$ & 197 & $\mathrm{Tc}$ & + & + & M85225 \\
\hline $\operatorname{tet}(\mathrm{M})$ & $\begin{array}{l}\text { GTP-binding elongation factor protein, TetM/TetO } \\
\text { family }\end{array}$ & 198 & Tc & + & + & X04388 \\
\hline $\operatorname{tet}(\mathrm{M})$ & $\begin{array}{l}\text { GTP-binding elongation factor protein, TetM/TetO } \\
\text { family }\end{array}$ & 198 & Tc & + & + & X90939 \\
\hline $\operatorname{tet}(\mathrm{O})$ & $\begin{array}{l}\text { GTP-binding elongation factor protein, TetM/TetO } \\
\text { family }\end{array}$ & 189 & Tc & + & - & Y07780 \\
\hline $\operatorname{tet}(\mathrm{S})$ & $\begin{array}{l}\text { GTP-binding elongation factor protein, TetM/TetO } \\
\text { family }\end{array}$ & 172 & Tc & + & + & L09756 \\
\hline $\operatorname{tet}(32)$ & $\begin{array}{l}\text { GTP-binding elongation factor protein, TetM/TetO } \\
\text { family }\end{array}$ & 149 & Tc & + & - & AJ295238 \\
\hline $\operatorname{tet}(36)$ & Ribosomal protection tetracycline resistance protein & 192 & Tc & - & + & AJ514254 \\
\hline $\operatorname{tet}(\mathrm{X})$ & Inactivation of tetracycline & 186 & Tc & + & + & M37699 \\
\hline$q a c B$ & $\begin{array}{l}\text { Permease of the MFS family, multidrug efflux } \\
\text { protein }\end{array}$ & 164 & Multidrug efflux & + & - & AF053771 \\
\hline qacE $\Delta 1$ & $\begin{array}{l}\text { Small multidrug resistance protein, membrane } \\
\text { transporter of cations and cationic drugs }\end{array}$ & 198 & QAC & + & + & AJ698325 \\
\hline$q a c F$ & $\begin{array}{l}\text { Small multidrug resistance protein, membrane } \\
\text { transporter of cations and cationic drugs }\end{array}$ & 195 & QAC & + & - & NC_007502 \\
\hline$q a c F, q a c H$ & $\begin{array}{l}\text { Small multidrug resistance protein, membrane } \\
\text { transporter of cations and cationic drugs }\end{array}$ & 172 & QAC & + & + & AY139598 \\
\hline
\end{tabular}


Table 2. cont.

\begin{tabular}{|c|c|c|c|c|c|c|}
\hline Gene name* & Gene product & $\begin{array}{l}\text { Amplicon size } \\
\quad \text { (bp) }\end{array}$ & $\begin{array}{l}\text { Resistance to/ } \\
\text { function } \dagger\end{array}$ & $\begin{array}{l}\text { Detected in } \\
\text { activated sludge }\end{array}$ & $\begin{array}{l}\text { Detected in the } \\
\text { final effluents }\end{array}$ & Accession no. \\
\hline qacG2 & $\begin{array}{l}\text { Small multidrug resistance protein, membrane } \\
\text { transporter of cations and cationic drugs }\end{array}$ & 147 & QAC & + & + & AJ609296 \\
\hline acrD & Cation/multidrug efflux pump & 185 & Aminoglycosides, $\mathrm{Nv}$ & + & + & U12598 \\
\hline $\operatorname{mex} B$ & $\begin{array}{l}\text { Cation/multidrug efflux pump, RND multidrug } \\
\text { efflux transporter }\end{array}$ & 147 & Multidrug efflux & + & + & L11616 \\
\hline $\operatorname{mex} D$ & RND multidrug efflux transporter & 185 & Em, Rox & + & + & NC_003430 \\
\hline $\operatorname{mexF}$ & $\begin{array}{l}\text { Cation/multidrug efflux pump, RND multidrug } \\
\text { efflux transporter }\end{array}$ & 348 & Multidrug efflux & + & + & X99514 \\
\hline mexI & $\begin{array}{l}\text { Cation/multidrug efflux pump, RND multidrug } \\
\text { efflux transporter }\end{array}$ & 170 & Multidrug efflux & + & + & AE004837 \\
\hline $\operatorname{mex} Y$ & $\begin{array}{l}\text { Cation/multidrug efflux pump, RND multidrug } \\
\text { efflux transporter }\end{array}$ & 198 & Multidrug efflux & + & + & AB015853 \\
\hline orf11 & $\mathrm{ABC}$ type permease & 198 & Nal, Nor & + & + & NC_006385 \\
\hline $\operatorname{trfA}$ & Replication initiation protein & 192 & $\begin{array}{l}\text { Initiation of replication, IncP- } \\
\text { specific gene }\end{array}$ & + & + & NC_004840 \\
\hline
\end{tabular}

${ }^{*}$ The PCR product is specific for all genes given in the field.

†Resistance spectra data were extracted from the respective database entry and the literature cited therein. Abbreviations: Ak, amikacin; Amo, amoxicillin; Amp, ampicillin; Atm, aztreonam; Azm, azithromycin; Car, carbenicillin; Caz, ceftazidim; Cec, cefaclor; Cfp, cefoperazon; Cft, ceftibuten; Cip, ciprofloxacin; Clr, clarithromycin; Cm, chloramphenicol; Cpo, cefpirom; Cro, ceftriaxon; Ctx, cefotaxime; Cxm, cefuroxime; Em, erythromycin; Fep, cefepim; Ffc, florfenicol; Fox, cefoxitin; Gm, gentamicin; Ipm, imipenem; Kf, cephalothin; Km, kanamycin; Lev, levofloxacin; Met, meticillin; MLS, macrolide-lincosamide-streptogramin B; Mez, mezlocillin; Nal, nalidixic acid; Neo, neomycin; Nor, norfloxacin; Nv, novobiocin; Ob, cloxacillin; Ofx, ofloxacin; Pen-G, penicillin G; Prl, piperacillin; QAC, quaternary ammonium compounds; Rif, rifampicin; Rox, roxithromycin; Spar, sparfloxacin; Sm, streptomycin; Sp, spectinomycin ; Sul, sulfonamides; Tc, tetracyclines; Tic, ticarcillin; Tob, tobramycin; Tp, trimethoprim; Ty, tylosin ¥Resistance genes recently described in clinical isolates. 
Table 3. Sequencing of randomly selected resistance-gene-specific amplicons obtained from wastewater treatment plant bacteria and annotation results

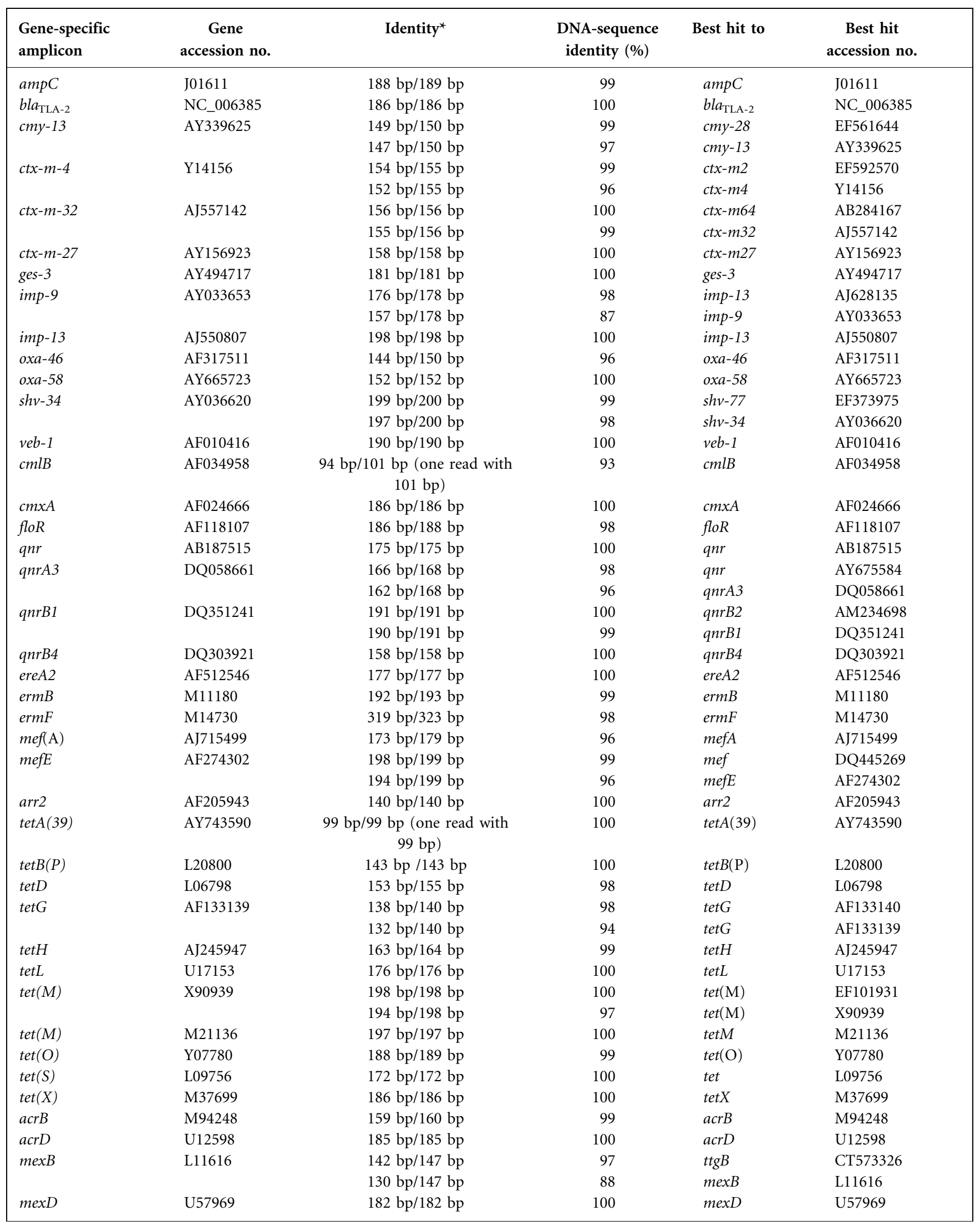


Table 3. cont.

\begin{tabular}{|c|c|c|c|c|c|}
\hline $\begin{array}{l}\text { Gene-specific } \\
\text { amplicon }\end{array}$ & $\begin{array}{c}\text { Gene } \\
\text { accession no. }\end{array}$ & Identity ${ }^{\star}$ & $\begin{array}{l}\text { DNA-sequence } \\
\text { identity }(\%)\end{array}$ & Best hit to & $\begin{array}{c}\text { Best hit } \\
\text { accession no. }\end{array}$ \\
\hline $\operatorname{mex} D$ & NC_003430 & $184 \mathrm{bp} / 185 \mathrm{bp}$ & 99 & $\operatorname{mex} D$ & NC_003430 \\
\hline \multirow[t]{2}{*}{$\operatorname{mex} F$} & X99514 & $348 \mathrm{bp} / 348 \mathrm{bp}$ & 100 & $\operatorname{mex} F$ & AE004091 \\
\hline & & $345 \mathrm{bp} / 348 \mathrm{bp}$ & 99 & $\operatorname{mex} F$ & X99514 \\
\hline $\operatorname{mexI}$ & AE004837 & $170 \mathrm{bp} / 170 \mathrm{bp}$ & 100 & $\operatorname{mexI}$ & $\begin{array}{l}\text { AE004837 (new } \\
\text { accession no. } \\
\text { AE004091) }\end{array}$ \\
\hline $\operatorname{mex} Y$ & AB015853 & 198 bp/198 bp & 100 & $\operatorname{mex} Y$ & $\mathrm{AB} 015853$ \\
\hline
\end{tabular}

${ }^{\star}$ In some cases the two best hits are given: (i) best hit to a related gene; (ii) hit to the reference gene.

effluents of the WWTP (123 genes) raises the question whether resistance genes recently described for clinical isolates are also present in and are released from the municipal sewage plant under study. It appeared that the aminoglycoside resistance genes aadA6/aadA10 (Fiett et al., 2006) and aac(3)-Id (Doublet et al., 2004), the $\beta$-lactam resistance genes $c t x-m-27$ (Bonnet et al., 2003), ctx-m-32 (Cartelle et al., 2004), ges-3 (Vourli et al., 2004), imp-9 (Xiong et al., 2006), imp-13 (Toleman et al., 2003) and oxa58 (Poirel et al., 2005), and the fluoroquinolone resistance genes qnrA3 (Heritier et al., 2004), qnrB1 (Jacoby et al., 2006) and qnrS (Hata et al., 2005), which were recently described as new genes or novel variants of known genes in clinical isolates, could be identified in the WWTP analysed (Table 2).

\section{Sequencing of selected resistance-gene-specific amplicons to verify their identity}

To verify the identity of the PCR products obtained in the analyses described above, 45 amplicons were randomly selected and sequenced. Sequencing and annotation results are summarized in Table 3. The nucleotide sequences of 20 amplicons (bla $a_{\mathrm{TLA}-2}, c t x-m 27$, ges-3, imp-13, oxa-58, veb-1, $c m \times A, q n r, q n r B 4, \operatorname{ere} A 2, \operatorname{arr} 2, \operatorname{tet} B(\mathrm{P}), \operatorname{tet} L, \operatorname{tet}(\mathrm{M}), \operatorname{tet}(\mathrm{S})$, tet $(\mathrm{X})$, acrD, mexD, mexI, mexY) are identical to the corresponding reference sequences, and eight amplicons ( ampC, ctx-m-32, qnrB1, ermB, tet H, tet $(\mathrm{O}), \operatorname{acr} B, \operatorname{mexD})$ display only one nucleotide exchange compared to the reference sequence. Moreover, the nucleotide sequences of 15 further amplicons are $87 \%$ to $98 \%$ identical to the corresponding reference gene. In the case of two amplicons, namely those for the genes $\operatorname{tet} A(39)$ and $c m l B$, only the sequence from one sequencing direction could be obtained. The resulting short sequence reads show, respectively, $100 \%$ identity (over a length of 99 bases) to tetA(39) and $93 \%$ identity (over a length of 101 bases) to cmlB. Although some amplicon sequences do not show the highest degree of identity to the corresponding reference resistance gene, they are very similar or even identical to a closely related resistance determinant. For example, the amplicon sequence obtained with primers designed on the resistance gene $c t x-m-32$ is identical to the sequence of $c t x$ $m-64$ and has only one mismatch compared to the reference gene $c t x-m-32$. These results show that the sequenced amplicons really contain resistance-gene-specific nucleotide sequences.

\section{Conclusions}

This comprehensive study provides evidence that bacteria residing in different compartments of the WWTP analysed harbour various plasmid-borne resistance determinants representing all common classes. To our best knowledge, this is the first study that describes detection of resistance genes known to confer resistance to all common classes of antibiotics in two different compartments of the same WWTP. The mobile pool of resistance genes shared by bacteria of the WWTP analysed even includes resistance genes that have only recently been described for clinical isolates, indicating genetic exchange between clinical and WWTP bacteria. Moreover, detection of these newer resistance genes on plasmids isolated from bacteria of the WWTP's final effluents confirms that these determinants are released into the environment, which might facilitate further dissemination among environmental bacteria. Moreover, it appeared that wastewater purification processes operating within the WWTP analysed are not appropriate to significantly reduce the spectrum of resistance genes that are detectable in the final effluents.

The composition of the plasmid pool analysed was biased, since plasmids were isolated from bacteria showing reduced susceptibility to different antibiotics. Accordingly, future projects will aim at the detection of antibiotic-resistance determinants in whole-community plasmid DNA preparations. In this context the microarray technology seems to be very well suited for simultaneous detection of hundreds of resistance determinants in samples derived from different WWTPs. Likewise, it would be informative to compare plasmid samples obtained from WWTPs that receive effluents from hospitals with those that are not connected to any medical facilities. 


\section{ACKNOWLEDGEMENTS}

The authors thank the Bioinformatics Resource Facility (BRF) at the CeBiTec of Bielefeld University for support regarding bioinformatics issues. The work was supported by the Landesamt für Natur, Umwelt und Verbraucherschuts NRW (Germany).

\section{REFERENCES}

Akinbowale, O. L., Peng, H. \& Barton, M. D. (2007). Diversity of tetracycline resistance genes in bacteria from aquaculture sources in Australia. J Appl Microbiol 103, 2016-2025.

Altschul, S. F., Gish, W., Miller, W., Myers, E. W. \& Lipman, D. J. (1990). Basic local alignment search tool. J Mol Biol 215, 403-410.

Bennett, P. M. (1999). Integrons and gene cassettes: a genetic construction kit for bacteria. J Antimicrob Chemother 43, 1-4.

Bönemann, G., Stiens, M., Pühler, A. \& Schlüter, A. (2006). Mobilizable IncQ-related plasmid carrying a new quinolone resistance gene, qnrS2, isolated from the bacterial community of a wastewater treatment plant. Antimicrob Agents Chemother 50, 3075-3080.

Bonnet, R., Recule, C., Baraduc, R., Chanal, C., Sirot, D., De Champs, C. \& Sirot, J. (2003). Effect of D240G substitution in a novel ESBL CTX-M27. J Antimicrob Chemother 52, 29-35.

Bywater, R. J. (2004). Veterinary use of antimicrobials and emergence of resistance in zoonotic and sentinel bacteria in the EU. J Vet Med B Infect Dis Vet Public Health 51, 361-363.

Bywater, R. J. (2005). Identification and surveillance of antimicrobial resistance dissemination in animal production. Poult Sci 84, 644-648.

Cartelle, M., del Mar Tomas, M., Molina, F., Moure, R., Villanueva, R. \& Bou, G. (2004). High-level resistance to ceftazidime conferred by a novel enzyme, CTX-M-32, derived from CTX-M-1 through a single Asp240-Gly substitution. Antimicrob Agents Chemother 48, 23082313.

Chee-Sanford, J. C., Aminov, R. I., Krapac, I. J., Garrigues-Jeanjean, N. \& Mackie, R. I. (2001). Occurrence and diversity of tetracycline resistance genes in lagoons and groundwater underlying two swine production facilities. Appl Environ Microbiol 67, 1494-1502.

Dang, H., Ren, J., Song, L., Sun, S. \& An, L. (2008). Diverse tetracycline resistant bacteria and resistance genes from coastal waters of Jiaozhou Bay. Microb Ecol 55, 237-246.

Davies, J. (1994). Inactivation of antibiotics and the dissemination of resistance genes. Science 264, 375-382.

Davison, J. (1999). Genetic exchange between bacteria in the environment. Plasmid 42, 73-91.

Doublet, B., Weill, F. X., Fabre, L., Chaslus-Dancla, E. \& Cloeckaert, A. (2004). Variant Salmonella genomic island 1 antibiotic resistance gene cluster containing a novel $3^{\prime}-\mathrm{N}$-aminoglycoside acetyltransferase gene cassette, aac(3)-Id, in Salmonella enterica serovar newport. Antimicrob Agents Chemother 48, 3806-3812.

Eichenlaub, R., Figurski, D. \& Helinski, D. R. (1977). Bidirection replication from a unique origin in a mini-F plasmid. Proc Natl Acad Sci U S A 74, 1138-1141.

Fiett, J., Baraniak, A., Mrowka, A., Fleischer, M., Drulis-Kawa, Z., Naumiuk, L., Samet, A., Hryniewicz, W. \& Gniadkowski, M. (2006). Molecular epidemiology of acquired-metallo-beta-lactamase-producing bacteria in Poland. Antimicrob Agents Chemother 50, 880-886.

Geisenberger, O., Ammendola, A., Christensen, B. B., Molin, S., Schleifer, K. H. \& Eberl, L. (1999). Monitoring the conjugal transfer of plasmid RP4 in activated sludge and in situ identification of the transconjugants. FEMS Microbiol Lett 174, 9-17.
Göbel, A., Thomsen, A., McArdell, C. S., Alder, A. C., Giger, W., Theiss, N., Löffler, D. \& Ternes, T. A. (2005). Extraction and determination of sulfonamides, macrolides, and trimethoprim in sewage sludge. J Chromatogr A 1085, 179-189.

Golet, E. M., Strehler, A., Alder, A. C. \& Giger, W. (2002). Determination of fluoroquinolone antibacterial agents in sewage sludge and sludge-treated soil using accelerated solvent extraction followed by solid-phase extraction. Anal Chem 74, 5455-5462.

Golet, E. M., Xifra, I., Siegrist, H., Alder, A. C. \& Giger, W. (2003). Environmental exposure assessment of fluoroquinolone antibacterial agents from sewage to soil. Environ Sci Technol 37, 3243-3249.

Goossens, H. (2005). European status of resistance in nosocomial infections. Chemotherapy 51, 177-181.

Gordon, D., Abajian, C. \& Green, P. (1998). Consed: a graphical tool for sequence finishing. Genome Res 8, 195-202.

Gordon, D., Desmarais, C. \& Green, P. (2001). Automated finishing with autofinish. Genome Res 11, 614-625.

Götz, A., Pukall, R., Smit, E., Tietze, E., Prager, R., Tschäpe, H., van Elsas, J. D. \& Smalla, K. (1996). Detection and characterization of broad-host-range plasmids in environmental bacteria by PCR. Appl Environ Microbiol 62, 2621-2628.

Guillaume, G., Verbrugge, D., Chasseur-Libotte, M., Moens, W. \& Collard, J. (2000). PCR typing of tetracycline resistance determinants (Tet A-E) in Salmonella enterica serotype Hadar and in the microbial community of activated sludges from hospital and urban wastewater treatment facilities in Belgium. FEMS Microbiol Ecol 32, $77-85$.

Hall, R. M. \& Collis, C. M. (1995). Mobile gene cassettes and integrons - capture and spread of genes by site-specific recombination. Mol Microbiol 15, 593-600.

Hata, M., Suzuki, M., Matsumoto, M., Takahashi, M., Sato, K., Ibe, S. \& Sakae, K. (2005). Cloning of a novel gene for quinolone resistance from a transferable plasmid in Shigella flexneri 2b. Antimicrob Agents Chemother 49, 801-803.

Henriques, I., Moura, A., Alves, A., Saavedra, M. J. \& Correia, A. (2006a). Analysing diversity among $\beta$-lactamase encoding genes in aquatic environments. FEMS Microbiol Ecol 56, 418-429.

Henriques, I. S., Fonseca, F., Alves, A., Saavedra, M. J. \& Correia, A. (2006b). Occurrence and diversity of integrons and $\beta$-lactamase genes among ampicillin-resistant isolates from estuarine waters. Res Microbiol 157, 938-947.

Heritier, C., Poirel, L. \& Nordmann, P. (2004). Genetic and biochemical characterization of a chromosome-encoded carbapenem-hydrolyzing ambler class D beta-lactamase from Shewanella algae. Antimicrob Agents Chemother 48, 1670-1675.

Heuer, H., Szczepanowski, R., Schneiker, S., Pühler, A., Top, E. M. \& Schlüter, A. (2004). The complete sequences of plasmids pB2 and pB3 provide evidence for a recent ancestor of the IncP-1 $\beta$ group without any accessory genes. Microbiology 150, 3591-3599.

Jacoby, G. A., Walsh, K. E., Mills, D. M., Walker, V. J., Oh, H., Robicsek, A. \& Hooper, D. C. (2006). qnrB, another plasmid-mediated gene for quinolone resistance. Antimicrob Agents Chemother 50, 1178-1182.

Jarnheimer, P. A., Ottoson, J., Lindberg, R., Stenstrom, T. A., Johansson, M., Tysklind, M., Winner, M. M. \& Olsen, B. (2004). Fluoroquinolone antibiotics in a hospital sewage line; occurrence, distribution and impact on bacterial resistance. Scand J Infect Dis 36, $752-755$.

Kümmerer, K. (2003). Significance of antibiotics in the environment. J Antimicrob Chemother 52, 5-7.

Kümmerer, K., Al-Ahmad, A. \& Mersch-Sundermann, V. (2000). Biodegradability of some antibiotics, elimination of the genotoxicity 
and affection of wastewater bacteria in a simple test. Chemosphere $\mathbf{4 0}$, 701-710.

Larkin, M. A., Blackshields, G., Brown, N. P., Chenna, R., McGettigan, P. A., McWilliam, H., Valentin, F., Wallace, I. M., Wilm, A. \& other authors (2007). CLUSTAL W and CLUSTAL_X version 2.0. Bioinformatics 23, 2947-2948.

Lee, H. B., Peart, T. E. \& Svoboda, M. L. (2007). Determination of ofloxacin, norfloxacin, and ciprofloxacin in sewage by selective solidphase extraction, liquid chromatography with fluorescence detection, and liquid chromatography-tandem mass spectrometry. J Chromatogr A 1139, 45-52.

Lim, S. M. \& Webb, S. A. (2005). Nosocomial bacterial infections in intensive care units. I. Organisms and mechanisms of antibiotic resistance. Anaesthesia 60, 887-902.

Lindberg, R. H., Wennberg, P., Johansson, M. I., Tysklind, M. \& Andersson, B. A. (2005). Screening of human antibiotic substances and determination of weekly mass flows in five sewage treatment plants in Sweden. Environ Sci Technol 39, 3421-3429.

Lindberg, R. H., Olofsson, U., Rendahl, P., Johansson, M. I., Tysklind, M. \& Andersson, B. A. (2006). Behavior of fluoroquinolones and trimethoprim during mechanical, chemical, and active sludge treatment of sewage water and digestion of sludge. Environ Sci Technol 40, 10421048.

Llanes, C., Gabant, P., Couturier, M., Bayer, L. \& Plesiat, P. (1996). Molecular analysis of the replication elements of the broad-host-range RepA/C replicon. Plasmid 36, 26-35.

Mach, P. A. \& Grimes, D. J. (1982). R-plasmid transfer in a wastewater treatment plant. Appl Environ Microbiol 44, 1395-1403.

Mancini, P., Fertels, S., Nave, D. \& Gealt, M. A. (1987). Mobilization of plasmid pHSV106 from Escherichia coli HB101 in a laboratoryscale waste treatment facility. Appl Environ Microbiol 53, 665-671.

Marcinek, H., Wirth, R., Muscholl-Silberhorn, A. \& Gauer, M. (1998). Enterococcus faecalis gene transfer under natural conditions in municipal sewage water treatment plants. Appl Environ Microbiol 64, 626-632.

Mazel, D. \& Davies, J. (1999). Antibiotic resistance in microbes. Cell Mol Life Sci 56, 742-754.

Nakata, H., Kannan, K., Jones, P. D. \& Giesy, J. P. (2005). Determination of fluoroquinolone antibiotics in wastewater effluents by liquid chromatography-mass spectrometry and fluorescence detection. Chemosphere 58, 759-766.

Nüßlein, K., Maris, D., Timmis, K. \& Dwyer, D. F. (1992). Expression and transfer of engineered catabolic pathways harbored by Pseudomonas spp. introduced into activated sludge microcosms. Appl Environ Microbiol 58, 3380-3386.

Poirel, L., Marqué, S., Héritier, C., Segonds, C., Chabanon, G. \& Nordmann, P. (2005). OXA-58, a novel class D $\beta$-lactamase involved in resistance to carbapenems in Acinetobacter baumannii. Antimicrob Agents Chemother 49, 202-208.

Prasher, D. C., Eckenrode, V. K., Ward, W. W., Prendergast, F. G. \& Cormier, M. J. (1992). Primary structure of the Aequorea victoria green-fluorescent protein. Gene 111, 229-233.

Rowe-Magnus, D. A. \& Mazel, D. (1999). Resistance gene capture. Curr Opin Microbiol 2, 483-488.

Rozen, S. \& Skaletsky, H. (2000). Primer3 on the WWW for general users and for biologist programmers. Methods Mol Biol 132, 365-386.

Sambrook, J., Fritsch, E. F. \& Maniatis, T. (1989). Molecular Cloning: a Laboratory Manual. Cold Spring Harbor, NY: Cold Spring Harbor Laboratory.

Schlüter, A., Heuer, H., Szczepanowski, R., Forney, L. J., Thomas, C. M., Pühler, A. \& Top, E. M. (2003). The 64508 bp IncP-1 $\beta$ antibiotic multiresistance plasmid $\mathrm{pB} 10$ isolated from a waste-water treatment plant provides evidence for recombination between members of different branches of the IncP-1 $\beta$ group. Microbiology 149, 31393153.

Schlüter, A., Heuer, H., Szczepanowski, R., Poler, S. M., Schneiker, S., Pühler, A. \& Top, E. M. (2005). Plasmid pB8 is closely related to the prototype IncP- $1 \beta$ plasmid R751 but transfers poorly to Escherichia coli and carries a new transposon encoding a small multidrug resistance efflux protein. Plasmid 54, 135-148.

Schlüter, A., Szczepanowski, R., Kurz, N., Schneiker, S., Krahn, I. \& Pühler, A. (2007a). Erythromycin resistance-conferring plasmid pRSB105, isolated from a sewage treatment plant, harbors a new macrolide resistance determinant, an integron-containing Tn402-like element, and a large region of unknown function. Appl Environ Microbiol 73, 1952-1960.

Schlüter, A., Krahn, I., Kollin, F., Bönemann, G., Stiens, M., Szczepanowski, R., Schneiker, S. \& Pühler, A. (2007b). IncP-1 $\beta$ plasmid pGNB1 isolated from a bacterial community from a wastewater treatment plant mediates decolorization of triphenylmethane dyes. Appl Environ Microbiol 73, 6345-6350.

Schlüter, A., Krause, L., Szczepanowski, R., Goesmann, A. \& Pühler, A. (2008). Genetic diversity and composition of a plasmid metagenome from a wastewater treatment plant. J Biotechnol 136, 6576.

Schwartz, T., Kohnen, W., Jansen, B. \& Obst, O. (2003). Detection of antibiotic-resistant bacteria and their resistance genes in wastewater, surface water, and drinking water biofilms. FEMS Microbiol Ecol 43, 325-335.

Seveno, N. A., Kallifidas, D., Smalla, K., van Elsas, J. D., Collard, J. M., Karagouni, A. D. \& Wellington, E. M. H. (2002). Occurrence and reservoirs of antibiotic resistance genes in the environment. Rev Med Microbiol 13, 15-27.

Smith, M. S., Yang, R. K., Knapp, C. W., Niu, Y., Peak, N., Hanfelt, M. M., Galland, J. C. \& Graham, D. W. (2004). Quantification of tetracycline resistance genes in feedlot lagoons by real-time PCR. Appl Environ Microbiol 70, 7372-7377.

Stiens, M., Becker, A., Bekel, T., Gödde, V., Goesmann, A., Niehaus, K., Schneiker-Bekel, S., Selbitschka, W., Weidner, S. \& other authors (2008). Comparative genomic hybridisation and ultrafast pyrosequencing revealed remarkable differences between the Sinorhizobium meliloti genomes of the model strain $\mathrm{Rm} 1021$ and the field isolate SM11. J Biotechnol 136, 31-37.

Szczepanowski, R., Krahn, I., Linke, B., Goesmann, A., Pühler, A. \& Schlüter, A. (2004). Antibiotic multiresistance plasmid pRSB101 isolated from a wastewater treatment plant is related to plasmids residing in phytopathogenic bacteria and carries eight different resistance determinants including a multidrug transport system. Microbiology 150, 3613-3630.

Szczepanowski, R., Braun, S., Riedel, V., Schneiker, S., Krahn, I., Pühler, A. \& Schlüter, A. (2005). The 120592 bp IncF plasmid pRSB107 isolated from a sewage-treatment plant encodes nine different antibiotic-resistance determinants, two iron-acquisition systems and other putative virulence-associated functions. Microbiology 151, 1095-1111.

Szczepanowski, R., Krahn, I., Bohn, N., Pühler, A. \& Schlüter, A. (2007). Novel macrolide resistance module carried by the IncP-1 $\beta$ resistance plasmid pRSB111, isolated from a wastewater treatment plant. Antimicrob Agents Chemother 51, 673-678.

Szczepanowski, R., Bekel, T., Goesmann, A., Krause, L., Krömeke, H., Kaiser, O., Eichler, W., Pühler, A. \& Schlüter, A. (2008). Insight into the plasmid metagenome of wastewater treatment plant bacteria showing reduced susceptibility to antimicrobial drugs analysed by the 454pyrosequencing technology. J Biotechnol 136, 54-64. 
Tauch, A., Schlüter, A., Bischoff, N., Goesmann, A., Meyer, F. \& Pühler, A. (2003). The 79,370 bp conjugative plasmid pB4 consists of an IncP-1 $\beta$ backbone loaded with a chromate resistance transposon, the strA-strB streptomycin resistance gene pair, the oxacillinase gene $b l a_{\mathrm{NPS}-1}$, and a tripartite antibiotic efflux system of the resistancenodulation-division family. Mol Genet Genomics 268, 570-584.

Tennstedt, T., Szczepanowski, R., Braun, S., Pühler, A. \& Schlüter, A. (2003). Occurrence of integron-associated resistance gene cassettes located on antibiotic resistance plasmids isolated from a wastewater treatment plant. FEMS Microbiol Ecol 45, 239-252.

Tennstedt, T., Szczepanowski, R., Krahn, I., Pühler, A. \& Schlüter, A. (2005). Sequence of the 68,869 bp IncP- $1 \alpha$ plasmid pTB11 from a waste-water treatment plant reveals a highly conserved backbone, a Tn402-like integron and other transposable elements. Plasmid 53, 218-238.

Toleman, M. A., Biedenbach, D., Bennett, D., Jones, R. N. \& Walsh, T. R. (2003). Genetic characterization of a novel metallo-betalactamase gene, bla IMP-13, harboured by a novel Tn5051-type transposon disseminating carbapenemase genes in Europe: report from the SENTRY worldwide antimicrobial surveillance programme. J Antimicrob Chemother 52, 583-590.

Volkmann, H., Schwartz, T., Bischoff, P., Kirchen, S. \& Obst, U. (2004). Detection of clinically relevant antibiotic-resistance genes in municipal wastewater using real-time PCR (TaqMan). J Microbiol Methods 56, 277-286.

Vourli, S., Giakkoupi, P., Miriagou, V., Tzelepi, E., Vatopoulos, A. C. \& Tzouvelekis, L. S. (2004). Novel GES/IBC extended-spectrum $\beta$ lactamase variants with carbapenemase activity in clinical enterobacteria. FEMS Microbiol Lett 234, 209-213.

Wassenaar, T. M. (2005). Use of antimicrobial agents in veterinary medicine and implications for human health. Crit Rev Microbiol 31, 155-169.

Xiong, J., Hynes, M. F., Ye, H., Chen, H., Yang, Y., M'Zali, F. \& Hawkey, P. M. (2006). $b l a_{\mathrm{IMP}-9}$ and its association with large plasmids carried by Pseudomonas aeruginosa isolates from the People's Republic of China. Antimicrob Agents Chemother 50, 355-358.

Edited by: L. Heide 